\section{EFFECTS OF N-ACETYL-CYSTEINE SUPPLEMENTATION ON EX-VIVO CLONOGENICITY AND OXIDATIVE PROFILE OF LINEAGE-COMMITTED HEMATOPOIETIC STEM/PROGENITOR CELLS}

Chan Chin Yi, Zariyantey Abd Hamid*, Izatus Shima Taib, Tan Hui Yee, Muhd Khairul Akmal Wak Harto, Chow Paik Wah

Program of Biomedical Science, School of Diagnostic and Applied Health Sciences, Faculty of Health Sciences, Universiti Kebangsaan Malaysia, Jalan Raja Muda Aziz, 50300 Kuala Lumpur, Malaysia
Article history

Received

3 August 2017

Received in revised form

19 October 2017

Accepted

15 January 2018

Published online

1 April 2018

*Corresponding author zyantey@ukm.edu.my

\section{Graphical abstract}

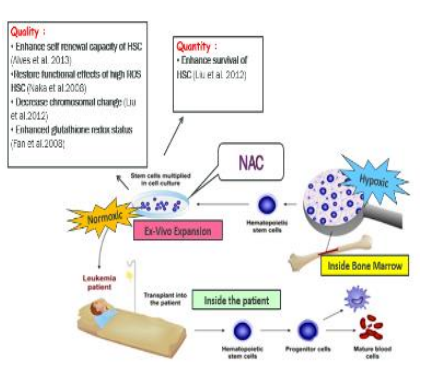

\begin{abstract}
Hematopoietic stem and progenitor cells (HSPCs) are exposed to oxidative damage acquired during ex vivo expansion which affects their therapeutic potency. Efforts to overcome this limitation includes the use of antioxidants. The effects of N-Acetyl-Cysteine (NAC) supplementation for 48 hours on maintenance of ex vivo HSPCs was investigated by examining the cell viability at concentrations of $0.125 \mu \mathrm{M}, 0.25 \mu \mathrm{M}, 0.5 \mu \mathrm{M}, 1.0 \mu \mathrm{M}$ and $2.0 \mu \mathrm{M}$, followed by clonogenicity and oxidative status assessments of lineage-committed progenitors (myeloid, erythroid and pre-B lymphoid) at selected NAC concentrations $(0.25 \mu \mathrm{M}, 0.5 \mu \mathrm{M}, 2.0 \mu \mathrm{M})$. NAC supplementation significantly $(\mathrm{p}<0.05)$ enhanced viability of HSPC at $0.25 \mu \mathrm{M}, 0.5 \mu \mathrm{M}, 2.0 \mu \mathrm{M}$. The clonogenicity of each progenitor was not affected as no significant changes of Colony Forming Units (CFUs) counts was noted between NAC-supplemented group than control. NAC showed no significant effects on reactive oxygen species (ROS), glutathione (GSH) and superoxide dismutase (SOD) levels of respective progenitors as compared to control. Conclusively, NAC shows potential property as antioxidant supplement for ex vivo maintenance of HSPCs by promoting survivability and maintaining clonogenicity.
\end{abstract}

Keywords: Hematopoietic stem/progenitor cells, N-Acetyl-Cysteine, ex vivo, clonogenicity, oxidative profile

\begin{abstract}
Abstrak
Sel stem/progenitor hematopoietik (SSPH) terdedah kepada kerosakan oksidatif semasa pengembangan ex vivo yang mempengaruhi potensi terapeutiknya. Antara usaha bagi mengatasi limitasi ini adalah melalui penggunaan antioksidan. Kesan suplementasi N-AcetylCysteine (NAC) selama 48 jam ke atas pengekalan ex vivo SSPH dikaji melalui analisa viabiliti sel pada kepekatan $0.125 \mu \mathrm{M}, 0.25 \mu \mathrm{M}, 0.5 \mu \mathrm{M}, 1.0 \mu \mathrm{M}$ dan $2.0 \mu \mathrm{M}$, diikuti dengan penentuan klonogenisiti dan profil oksidatif progenitor berlainan keturunan (mieloid, eritroid dan limfoid pre-B) pada kepekatan NAC terpilih $(0.25 \mu \mathrm{M}, 0.5 \mu \mathrm{M}$ dan $2.0 \mu \mathrm{M})$. Suplementasi NAC meningkatkan viabiliti SSPH secara signifikan ( $p<0.05$ ) pada kepekatan $0.25 \mu \mathrm{M}, 0.5 \mu \mathrm{M}$, dan $2.0 \mu \mathrm{M}$. Klonogenisiti bagi setiap progenitor tidak dipengaruhi berdasarkan tiadanya perbezaan signifikan pada bilangan unit pembentuk koloni (CFUs) antara kumpulan disuplementasi NAC berbanding kawalan. Progenitor yang disuplementasi NAC menunjukkan tiada perbezaan yang signifikan bagi aras spesies oksigen reaktif (ROS), glutation (GSH) dan superoxide dismutase (SOD) berbanding kawalan. Kesimpulannya, NAC menunjukkan potensi
\end{abstract}


sebagai suplemen antioksidan untuk pengekalan SSPH secara ex vivo melalui keupayaannya merangsang kemandirian sel dan mengekalkan klonogenisiti.

Keywords: Sel stem/progenitor hematopoietik, N-Acetyl-Cysteine, ex vivo, klonogenisiti, profil oksidatif

\subsection{INTRODUCTION}

Hematopoietic stem and progenitor cells (HSPCs) have infinite self-renewal capacity and ability to differentiate into matured blood cells in the body. These properties offered a valuable source for HSPCs transplantation for the treatment of various hematological disorders and bone marrow failure [1]. However, HSPCs transplantation have been hampered by several features, which includes the application of extensive procedures to harvest the HSPCs, the number of useful cells obtained is limited and the kinetic of regeneration of mature blood cells after transfusion are not ideal [2]. Therefore, ex vivo expansion and maintenance of HSPCs is crucial prior to its therapeutic application.

Numerous studies demonstrated that the fate of HSPCs is regulated by the microenvironment of socalled "stem cell niches" which have oxygen saturations of around $5 \%[3,4]$. However, the unique characteristic of the HSPCs often altered once they leave the hypoxic bone marrow niche, which will affect the quality and quantity of the ex vivo expanded HSPCs. This limitation raises concern regarding the ability of ex vivo maintained HSPCs to retain their native properties which are required for a successful transplantation.

Various strategies have been developed for ex vivo expansion of HSPCs. These includes the utility of transcription factors, co-culturing with feeder cells [5], addition of cytokines cocktails [6] and genetic modification [7]. However, these approaches have some drawbacks where longer duration of more than 2 weeks are required to produce sufficient amounts of HSPCs via co-culture [5], the use of cytokines cocktails and transcription factors which are costly for long term cultures $[5,6]$ and insertional mutagenesis associated with genetic manipulation [7].

The normoxic condition in the ex vivo culture as compared to native hypoxic condition in the bone marrow niche has been associated with greater oxidative stress exposure affecting HSPCs survivability and functionality $[8,9]$. Meanwhile, the reactive oxygen species (ROS) has been reported to play a significant role as signaling molecules in mediating the crosstalk between metabolism and stem cell fate decisions [10, 11, 12]. Studies have shown that moderately high ROS levels prime HSPCs for differentiation, whereas those cells with low levels of ROS retain their long-term self-renewal capability [13, $14,15]$.

The higher oxygen tension in normoxic condition during ex vivo culture promotes greater ROS production [16], leading to various oxidative damages including genomic instability [8] imbalance in the antioxidative enzyme and impaired self-renewal and multipotency capacities [17] of HSPCs. Thus, a number of studies have suggested the use of antioxidant to overcome these limitations. A Japanese herbal medicine made from ten different herbs, TJ-48 (Juzentaiho-to or Shi Quan-Da- Bu-Tang), showed positive effect on ex vivo hematopoietic restoration [18]. Besides, the usage of Hibiscus sabdariffa L. (Roselle) able to enhance the survivability of hematopoietic stem cells (HSCs) by restoring the intracellular antioxidant enzyme [9].

$\mathrm{N}$-Acetyl-Cysteine (NAC) has been used as an antioxidant precursor to glutathione in the treatment of paracetamol overdose [19], chronic obstructive pulmonary disease and contrast-induced nephropathy [20]. NAC is a thiol-containing compound that is able to interfere with redox transitions of thiols and thus able to modulate redox signaling [21]. NAC is a potent antioxidant due to ROS scavenging ability, leading to inhibition of ROSinduced cellular damage and apoptosis [22, 17]. A number of studies concerning the use of $\mathrm{N}$-AcetylCysteine (NAC) to maintain the cultured HSCs ex vivo has been reported. These includes proper dosage $(0.1$ $\mu M)$ of NAC for 48 hours were found to decrease the rates of chromosomal aberrations in HSCs; thus improving the survivability of HSCs in in vitro cultures [8]. Moreover, greater CD34+ cells were obtained following cultivation with $2 \mathrm{mM}$ of NAC for 7 days under normoxia in ex vivo culture [23]. However, no study to date investigating the effects of NAC targeting HSPCs of different lineage of myeloid, erythroid and pre-B lymphoid in terms of their clonogenicity and oxidative status. Thus assessment targeting lineage-committed HSPCs which represents fundamental population of HSPCs are important to ensure long-term maintenance of hematopoiesis. 


\subsection{METHODOLOGY}

\subsection{N-Acetyl-Cysteine (NAC)}

The NAC used in this study was purchased from Sigma Aldrich company which is Sigma Grade, $\geq 99 \%$ (TLC), powder. Briefly, prior to usage, phosphate buffer saline (PBS) was used to dilute the NAC powder to obtain the stock solution. Then, the solution was filtered by using a filter with pore size $0.22 \mu \mathrm{M}$ in the laminar flow hood and the working solution was prepared by using serial dilutions.

\subsection{Experimental Protocols}

All procedures involving the use of laboratory animals was reviewed and approved by the UKM Animal Ethics Committee (Ethics Approval Number: FSK/2016/ZARIYANTEY/27-JULY/773-JULY-2016-JUNE2017-AR-CAT2). Bone marrow-derived hematopoietic stem cells were isolated from $30-35 \mathrm{~g}$ weighed male ICR (Imprinting Control Region)-strain mice. After cervical dislocation, long bones (tibia and femur) were isolated from the mice, flushing technique was applied to flush the bone marrow cells (BMCs) from the long bones [9]. Briefly, the harvested cells were filtered through a $40 \mu \mathrm{M}$ cell strainer, centrifuged at 2500 rpm, 7 minutes and re-suspended in complete HSPCs culture medium of DMEM supplemented with $10 \% \mathrm{FBS}$ and $1 \%$ Penicillin/ Streptomycin, $100 \mathrm{ng} / \mathrm{ml}$ Stem Cell Factor (SCF), $10 \mathrm{ng} / \mathrm{ml}$ Interleukin-6 (IL-6), and $5 \mathrm{ng} / \mathrm{ml}$ Interleukin-3 (IL-3). Cell viability was determined by trypan blue exclusion test and, routinely, around $1 \times 10^{7}$ cells will be obtained from one mouse. Cell suspension was seeded into HSPCs growth media enriched with SCF, IL-3 and IL-6 for 24 hours followed by NAC supplementations at $0.125 \mu \mathrm{M}$, $0.25 \mu \mathrm{M}, 0.5 \mu \mathrm{M}, 1.0 \mu \mathrm{M}$ and $2.0 \mu \mathrm{M}$ [8] for additional 48 hours. The selected time point of 48 hours for NAC supplementation is based on study by Liu et al. (2012). Cells without NAC supplementation served as the control group. After 48 hours, cell viability was determined using trypan blue exclusion test. Then, selected concentrations of NAC $(0.25 \mu \mathrm{M}, 0.5 \mu \mathrm{M}$ and $2.0 \mu \mathrm{M}$ ) were used for downstream analysis comprise of clonogenicity and oxidative profile assessment of respective progenitors of myeloid, erythroid and pre-B lymphoid progenitors.

\subsection{Viability Assessment by Trypan Blue Exclusion Test}

Cell viability was assessed by using trypan blue exclusion test. Briefly, bone marrow cells were seeded into 24-well plates at seeding density of $1 \times 10^{6} \mathrm{cells} / \mathrm{ml}$ at HSPCs growth medium. Then, cells were supplemented with NAC at concentrations of 0.125 $\mu \mathrm{M}, 0.25 \mu \mathrm{M}, 0.5 \mu \mathrm{M}, 1.0 \mu \mathrm{M}$ and $2.0 \mu \mathrm{M}$. After 48 hours, cells were harvested and counted by using haemocytometer using trypan blue exclusion method [24].

\subsection{Clonogenicity Assessment by Colony-Forming Units (CFUs) Assay}

The CFUs assay was performed following the protocol as described by Stem Cell Technologies 2015 using MethocultTM GF M 3534 to culture CFU-granulocyte and macrophage (CFU-GM) progenitor, Methocult'TM GF M 3630 to culture pre-B lymphoid progenitor and MethocultTM GF M 3334 to culture CFU-erythroid (CFUE) progenitor. Briefly, after 48 hours of NAC supplementation $(0.25 \mu \mathrm{M}, 0.5 \mu \mathrm{M}$ and $2.0 \mu \mathrm{M})$ supplementation, the cell viability in each experimental group was determined using trypan blue exclusion test. Then, bone marrow cells were collected and plated into methylcellulose agar for respective progenitors at the following density; $2 \times 10^{5}$ cells for myeloid, $2 \times 10^{6}$ cells for pre-B lymphoid and 1 $\times 10^{6}$ cells for erythroid. Culture were incubated at 37 ${ }^{\circ} \mathrm{C}$ in $5 \% \mathrm{CO}_{2}$ incubator. Colonies were then identified and counted for pre-B lymphoid and erythroid progenitors following 7 days of incubation, while 14 days are required for myeloid progenitor. The total colonies formed by respective progenitors were then counted to determine clonogenicity of each lineage. Colonies with more than 30 cells were included for analysis [25].

\subsection{Determination of Reactive Oxygen Species (ROS)}

The level of ROS was measured with hydroethidine (HE) staining. Briefly, after culturing for 7 days for pre-B lymphoid and erythroid progenitors and 14 days for myeloid progenitor, the CFUs of respective progenitors from each experimental group was harvested where the agar was diluted by using phosphate buffer saline. Then, the harvested cells were centrifuged at 2500 rpm for 7 minutes. Cells were then re-suspended in 1 $\mathrm{ml}$ pre-warmed unenriched DMEM medium and loaded with $\mathrm{HE}(10 \mathrm{mM})$ for 30 minutes at $37{ }^{\circ} \mathrm{C}$ in $5 \%$ $\mathrm{CO}_{2}$ incubator. ROS production was quantified by measuring the intensity of $\mathrm{HE}$ fluorescence using flow cytometry. ROS levels were then determined using mean fluorescence intensities and expressed as percentages of ROS producing cells.

2.6 Determination of Glutathione (GSH) Level and Superoxide Dismutase (SOD) Activity

Briefly, following 7 days of CFUs assay for pre-B lymphoid and erythroid progenitors and 14 days for myeloid progenitor, the CFUs of respective progenitors from each experimental group were harvested and cell lysate were prepared and protein level were determined with Bradford assay prior to antioxidant analysis. Quantification of GSH which represent the intracellular content of non-enzymatic antioxidant was achieved using spectrophotometric assay, which involves oxidation of GSH by the sulfhydryl reagent 5,5'-dithio-bis (2-nitrobenzoic acid) (DTNB) to form the yellow derivative 5'-thio-2-nitrobenzoic acid (TNB) that 
was measurable at $412 \mathrm{~nm}$ [26] GSH levels was expressed as $\mu \mathrm{mol} / \mathrm{mg}$. As for SOD, the activity was assayed based on the inhibition of nitrobluetetrazolium (NBT) reduction [27]. The reduction of NBT by superoxide radicals to blue coloured formazan was followed at $560 \mathrm{~nm}$. "One unit (1U) of SOD activity is defined as that amount of SOD required to inhibit the reduction of NBT by $50 \%$ under the specified conditions". SOD activity was expressed as U/min/mg.

\subsection{Statistical Analysis}

Each experiment was repeated for at least three times using bone marrow cells from three independent mice. The data are presented as means \pm standard error mean. Statistical analysis was conducted using SPSS version 22.0 (IBM Corporation, Armonk, New York, USA), and $p<0.05$ was considered statistically significant. One independent T-test was employed to test differences of studied parameters between the NAC-supplemented and control groups.

\subsection{RESULTS AND DISCUSSION}

3.1 Effects of NAC Supplementation on the Viability of Hematopoietic Stem and Progenitor Cells (HSPCs)

The viability of HSPCs were increased in the presence of NAC as compared to control group (Figure 1). NAC supplementation enhanced the viability of HSPCs significantly $(\mathrm{p}<0.05)$ at $0.25 \mu \mathrm{M}(164 \pm 12.34 \%), 0.5$ $\mu \mathrm{M}(160 \pm 7.74 \%)$ and $2.0 \mu \mathrm{M}(123 \pm 5.75 \%)$ then the noted viability for control group (100 $\pm 0 \%$ ).

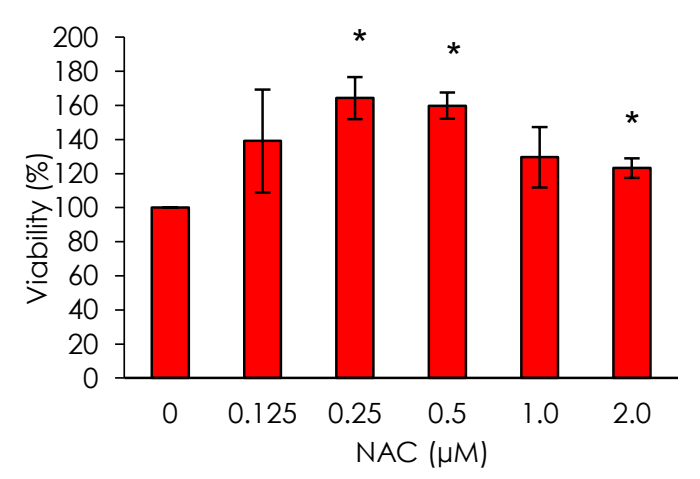

Figure 1 Effects of NAC supplementation on viability of HSCS. Cell viability (\%) was determined by Trypan Blue Exclusion Test. Data are presented as the mean \pm S.E.M $(n=3) .{ }^{*}$ indicates significant differences $(p<0.05)$ compared to control group
3.2 Effects of NAC Supplementation on Clonogenicity of Myeloid, Erythroid and Pre-B Lymphoid Progenitors

The total CFUs were counted (Figure 2) and were characterized morphologically (Figure 3) under inverted microscope following 7 days of incubation for pre-B lymphoid and erythroid progenitors and 14 days for myeloid progenitors. There was no significant difference on the clonogenicity of myeloid, erythroid and pre-B lymphoid progenitors between NACsupplemented and control groups. The colonies count of control group for myeloid progenitor was $169 \pm 22$ colonies while, for NAC supplemented groups, the colonies count were $154 \pm 10$ colonies, $177 \pm 23$ colonies and $152 \pm 22$ colonies at NAC concentrations of $0.25 \mu \mathrm{M}, 0.5 \mu \mathrm{M}$ and $2.0 \mu \mathrm{M}$, respectively. On the other hand, the colonies count of control group for erythroid progenitor was $88 \pm 2$ colonies while, for NAC supplemented groups the colonies count were $84 \pm 3$ colonies, $65 \pm 14$ colonies and $69 \pm 8$ colonies at NAC concentrations of $0.25 \mu \mathrm{M}, 0.5 \mu \mathrm{M}$ and $2.0 \mu \mathrm{M}$, respectively. Next, the colonies count of control groups for pre-B lymphoid progenitor was $47 \pm 6$ colonies while, for NAC supplemented groups, the colonies count were $48 \pm 5$ colonies, $42 \pm 11$ colonies and $34 \pm 12$ colonies at NAC concentrations of 0.25 $\mu \mathrm{M}, 0.5 \mu \mathrm{M}$ and $2.0 \mu \mathrm{M}$, respectively.

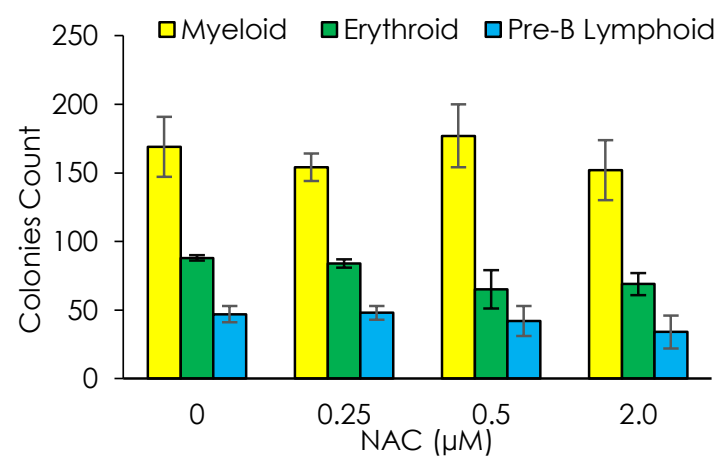

Figure 2 Effect of NAC supplementation on the clonogenicity of myeloid, erythroid and pre-B lymphoid progenitors using colony forming unit assay of respective progenitor. Data are presented as the mean \pm S.E.M $(n=3)$

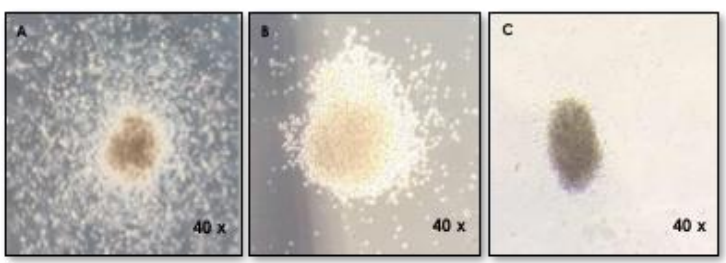

Figure 3 Image representing colony-forming units of respective progenitors. Each type of colony was counted and characterized after 7 days or 14 days of culture based on the respective morphology as follows: A: CFU-GM (colonyforming unit- granulocyte and macrophage), B: CFU-E (colony-forming unit- erythroid) and C: Pre-B Lymphoid. (Magnification: $40 \mathrm{x}$ ) 


\subsection{Effects of NAC Supplementation on the ROS Level} of Myeloid, Erythroid and Pre-B Lymphoid Progenitors

The role of NAC supplementation in the oxidative stress status of myeloid, erythroid and pre-B lymphoid progenitors was investigated by measuring the level of ROS. As illustrated in Figure 4, the ROS level of control group for myeloid progenitor was $4.37 \pm 0.17 \%$ while, $4.03 \pm 0.43 \%, 4.17 \pm 1.24 \%$ and $3.93 \pm 1.04 \%$ of ROS were noted at NAC concentrations of $0.25 \mu \mathrm{M}, 0.5 \mu \mathrm{M}$ and $2.0 \mu \mathrm{M}$, respectively. Meanwhile, the ROS level of control group for erythroid progenitor was $4.70 \pm 0.98 \%$ followed by $5.60 \pm 0.25 \%, 2.50 \pm 1.66 \%$ and $6.47 \pm$ $3.72 \%$ at NAC concentrations of $0.25 \mu \mathrm{M}, 0.5 \mu \mathrm{M}$ and $2.0 \mu \mathrm{M}$, respectively. Next, the ROS level of control group for pre-B lymphoid progenitor was $4.47 \pm 0.83 \%$ which was then followed by $2.93 \pm 0.38 \%, 2.43 \pm 0.58 \%$ and $2.77 \pm 0.78 \%$ at NAC concentrations of $0.25 \mu \mathrm{M}$, $0.5 \mu \mathrm{M}$ and $2.0 \mu \mathrm{M}$, respectively.

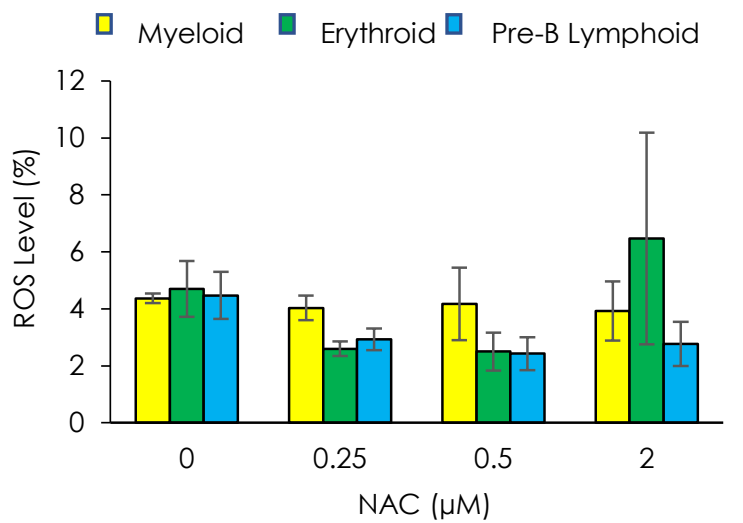

Figure 4 Effect of NAC supplementation on ROS level of respective progenitors. Data are presented as the mean \pm S.E.M $(n=3)$

3.4 Effects of NAC Supplementation on GSH Level of Myeloid, Erythroid and Pre-B Lymphoid Progenitors

As presented in Figure 5, there was no significant difference on the level of GSH for myeloid, erythroid and pre-B lymphoid progenitors between NACsupplemented and control groups. The GSH level of control group for myeloid progenitor was $0.20 \pm 0.02$ $\mu \mathrm{mol} / \mathrm{mg}$. In the presence of NAC, the recorded levels were $0.25 \pm 0.02 \mu \mathrm{mol} / \mathrm{mg}, 0.25 \pm 0.03 \mu \mathrm{mol} / \mathrm{mg}$, and $0.34 \pm 0.07 \mu \mathrm{mol} / \mathrm{mg}$ at NAC concentrations of 0.25 $\mu \mathrm{M}, 0.5 \mu \mathrm{M}$ and $2.0 \mu \mathrm{M}$, respectively. As for erythroid progenitor, the GSH level of control group was $0.74 \pm$ $0.12 \mu \mathrm{mol} / \mathrm{mg}$, and in the presence of NAC, the notable level of $0.77 \pm 0.37 \mu \mathrm{mol} / \mathrm{mg}, 0.88 \pm 0.57$ $\mu \mathrm{mol} / \mathrm{mg}$ and $0.62 \pm 0.39 \mu \mathrm{mol} / \mathrm{mg}$ were recorded for NAC concentrations of $0.25 \mu \mathrm{M}, 0.5 \mu \mathrm{M}$ and $2.0 \mu \mathrm{M}$, respectively. Meanwhile, the GSH level of control group for pre-B lymphoid progenitor was $1.18 \pm 0.16$ $\mu \mathrm{mol} / \mathrm{mg}$, followed by $1.02 \pm 0.62 \mu \mathrm{mol} / \mathrm{mg}, 0.79 \pm 0.43$ $\mu \mathrm{mol} / \mathrm{mg}$ and $0.84 \pm 0.35 \mu \mathrm{mol} / \mathrm{mg}$ at NAC concentrations of $0.25 \mu \mathrm{M}, 0.5 \mu \mathrm{M}$ and $2.0 \mu \mathrm{M}$, respectively.

Myeloid Erythroid $\square$ Pre-B Lymphoid

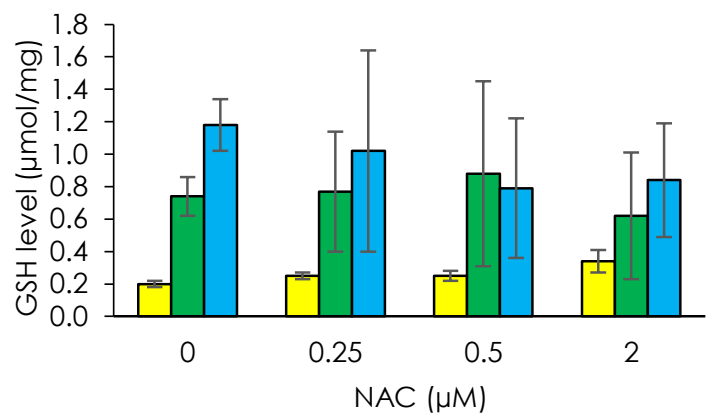

Figure 5 Effect of NAC supplementation on GSH level of respective progenitors. Data are presented as the mean \pm S.E.M $(n=3)$

3.5 Effects of NAC Supplementation on SOD Activity of Myeloid, Erythroid and Pre-B Lymphoid Progenitors

SOD analysis showed no significant difference on the SOD activity of myeloid, erythroid and pre-B lymphoid progenitors between NAC-supplemented and control groups as shown in Figure 6. The SOD activity for control group of myeloid progenitor was $260.61 \pm 47.21$ $\mathrm{U} / \mathrm{min} / \mathrm{mg}$ while, for group that received $0.25 \mu \mathrm{M}, 0.5$ $\mu \mathrm{M}$ and $2.0 \mu \mathrm{M}$ of NAC, the recorded SOD activity was $290.46 \pm 34.65 \mathrm{U} / \mathrm{min} / \mathrm{mg}, 215.72 \pm 54.37 \mathrm{U} / \mathrm{min} / \mathrm{mg}$ and $146.10 \pm 15.60 \mathrm{U} / \mathrm{min} / \mathrm{mg}$ respectively. Meanwhile, the SOD activity for control group of erythroid progenitor was $76.19 \pm 23.09 \mathrm{U} / \mathrm{min} / \mathrm{mg}$ while, for group that received $0.25 \mu \mathrm{M}, 0.5 \mu \mathrm{M}$ and $2.0 \mu \mathrm{M}$ of NAC, the recorded SOD activity was $106.69 \pm 38.50 \mathrm{U} / \mathrm{min} / \mathrm{mg}$, $99.24 \pm 40.10 \mathrm{U} / \mathrm{min} / \mathrm{mg}$ and $114.13 \pm 20.35 \mathrm{U} / \mathrm{min} / \mathrm{mg}$ respectively. Furthermore, the SOD activity for control group of pre-B lymphoid progenitor was $36.85 \pm 7.10$ $\mathrm{U} / \mathrm{min} / \mathrm{mg}$ followed by the group that received 0.25 $\mu \mathrm{M}, 0.5 \mu \mathrm{M}$ and $2.0 \mu \mathrm{M}$ of NAC which showed the SOD activity at $108.49 \pm 52.46 \mathrm{U} / \mathrm{min} / \mathrm{mg}, 93.42 \pm 39.71$ $\mathrm{U} / \mathrm{min} / \mathrm{mg}(\mathrm{p}=0.233)$ and $83.23 \pm 28.74 \mathrm{U} / \mathrm{min} / \mathrm{mg}$ respectively.

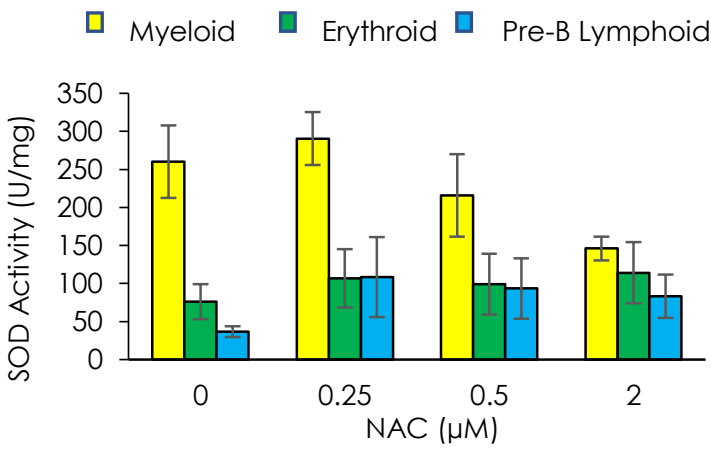

Figure 6 Effect of NAC supplementation on SOD activity of respective progenitors. Data are presented as the mean \pm S.E.M $(n=3)$ 


\subsection{RESULTS AND DISCUSSION}

HSPCs with self-renewal and multipotency capacity offer valuable source for cell-based therapy and regenerative medicine [9]. However, due to some limitations occur in the HSPCs transplantation, ex vivo expansion and maintenance of HSPCs is very crucial. But, the unique characteristics of the HSPCs often altered once they leave the hypoxic bone marrow niche which will affect the quality and quantity of the cultured HSPCs. Studies showed that fate of HSPCs is regulated by the microenvironment of so-called "stem cell niches" which have oxygen saturations of around $5 \%[3,4]$. However, the increased oxygen tension in the normoxic culture will cause stem cells to loss their stem-ness [8, 16]. Hence, to ensure the safety and efficacy of hematopoietic stem cell-based therapy, proper maintenance of cultured HSPCs is very important.

Various attempts have been used to maintain the stem-ness of HSPCs and to overcome the limitations associated with ex vivo culture. These include the utility of transcription factors, co-culturing with feeder cells [5], addition of cytokines cocktails [6] and genetic modification [7]. However, these approaches have some drawbacks. Many researchers also suggested the use of antioxidant to overcome the oxidative stress mediated damage in cultured HSPCS $[15,28]$. A number of studies have demonstrated the potential use of $\mathrm{N}$-Acetyl-Cysteine (NAC) in ex vivo maintenance of HSCs [8, 23]. N-Acetyl-Cysteine (NAC) is a thiol containing antioxidant which have the ROS scavenging ability. It has the ability to facilitate glutathione biosynthesis and inhibition of ROS induced cellular damage and apoptosis [22, 29]. Besides, the ability of the sulfhydryl groups of NAC to interact with ROS in the HSCs enable the maintenance of selfrenewal properties of the stem cells [15].

This study has shown that NAC enhanced the viability of HSPCs significantly at NAC concentrations of $0.25,0.5$ and $2.0 \mu \mathrm{M}$ following 48 hours of culture (Subsection 3.1, Figure 1). Our finding is in accordance to a previous finding by Liu et al. (2012) of which demonstrated that proper dosage of NAC decreased the occurrence of chromosomal aberration and consequently enhanced the survivability of HSCs in vitro [8]. In 2008, Fan et al. also demonstrated that addition of NAC was able to increase percentage of CD34+ cells survivability following 7 days of culture [23]. Increment in the cell viability after NAC supplementation also indicates that NAC may able to maintain the self-renewal potency of HSPCs. Similarly, Ito et al. (2006) also reported that NAC was able to enhance the self-renewal capacity of HSPCs. Hence, our finding may indicate the usefulness of NAC supplementation in ex vivo expansion and maintenance of HSPCs potency prior to clinical application [15].

Population of HSPCs are multipotent cells that able to differentiate into progenitors of respective myeloid, erythroid and lymphoid lineages, which represents their functional property. Hence, it is crucial to identify the effect of NAC supplementation on the lineage commitment of HSPCs to these respective progenitors. To address this issue, we have investigated the differentiation potency of HSPCs to progenitors of respective lineage namely myeloid, erythroid and pre-B lymphoid using clonogenic assay. We found that NAC showed no significant effects on the clonogenicity of myeloid, erythroid and pre-B lymphoid progenitors as compared to control (Subsection 3.2, Figure 2 \& 3). These findings reflect that NAC is neither enhance nor inhibit clonogenicity of each progenitor. Previously, NAC treatment able to reduce radiation-induced genotoxicity and cytotoxicity effects in rat bone marrow cells following in-vivo administration for 72 hours, suggesting the ability of NAC to confer protection on hematopoietic stem/progenitor populations [30]. Up to our knowledge, none of the study has investigated the use of NAC targeting HSPCs of different lineages in terms of their clonogenicity. Thus at this stage of finding, a definite conclusion cannot be ruled out and future study concerning ex vivo maintenance of the respective progenitors deserves further investigation.

It had been well established that sustain selfrenewal and inhibition of differentiation of HSCs in ex vivo expansion are very crucial [16] and ROS plays an important role in determining the stem cell fate. Evidence proves that low ROS level are critical for maintaining the self-renewal capacity of HSCs which indicate the stem-ness property [31]. Recent studies showed that $2 \mathrm{mM}$ of NAC supplementation in normoxic condition able to regulate the intercellular ROS of cultured HSPCs close to under hypoxia [23]. In the present study, without NAC supplementation, we noticed that the baseline level of ROS of every progenitor was almost similar which is around $4-5 \%$. In general, there are no significant differences was noted for the ROS level between the control and NACsupplemented groups. However, notable selective effect of NAC on the pre-B lymphoid progenitor was evidenced whereby the level of ROS was consistently lower in NAC-supplemented groups as compared to control (Subsection 3.3, Figure 4). The results implied that ROS level encounter by every lineage was almost similar and NAC has potential to decrease the ROS level in pre-B lymphoid progenitor.

For more insight of the evidences in changes of oxidative balance in myeloid, erythroid and pre-B lymphoid progenitors, GSH level and SOD activity were analysed. Our attempt is a pilot study to identify the effect of antioxidant supplementation on the antioxidant status of hematopoietic progenitors for respective lineage. Up to our knowledge, there is no study has been conducted to date concerning this aspects. Thus our study may open a new niche for exploration which could uncover new understanding pertaining antioxidant profiles of respective progenitors. In 2008, a study by Fan et al. reported that 
glutathione(GSH)-glutathione peroxidase (GPX) antioxidant system played an important role in preservation of $\mathrm{CD} 34^{+}$cells by reducing the level of peroxidation. Meanwhile, the addition of NAC promotes the proliferation of $\mathrm{CD}_{4} 4^{+}$cells and enhances the intracellular level of GSH [23]. Our data indicated a difference in baseline level of the antioxidants status (GSH and SOD) among progenitor of different lineages as evidenced in control group of respective progenitor. The finding may imply that different progenitors may acquire differential response of antioxidative system, suggesting the need to consider this variation for future research.

From our findings, the levels of GSH and SOD of respective myeloid, erythroid and pre-B lymphoid progenitors were not significantly affected following NAC supplementation as compared to control. However, an increased level of GSH in myeloid progenitors was noted (Subsection 3.4, Figure 5). In contrast, an increased SOD level was seen for erythroid and pre-B lymphoid progenitors (Subsection 3.5, Figure 6). This finding may suggest that the progenitors with single lineage commitment (erythroid and pre-B lymphoid) may acquire differential antioxidant capacity as compared to multi-lineage committed progenitor (myeloid). However, future study concerning this event deserves further investigation.

HSCs are being applied widely not only for therapeutic applications, but they are also being used actively in research activities for various purposes. In clinical practice, there is no specific recommendation concerning suitable expansion period for HSCs. In most cases, the harvested HSCs will be cryopreserved and if immediate cryopreservation was not available, the recommended storage time-points prior to transplantation is within 48 to 72 hours from collection at storage temperatures of 20 to $24^{\circ} \mathrm{C}$ and 2 to $6^{\circ} \mathrm{C}$, respectively [33]. In term of quality requirement of HSCs product prior to transplantation, the monitored factors comprised of cell counts, microbiology testing and antigen compatibility for transplant [33]. Thus, we postulate that future guideline may need to consider additional quality aspects such as oxidative damage and stem cells potency prior to clinical usage to avoid potential harmful side effects from the use of incompetence and unsafe cell products. Moreover, the time-point of 48 hours as employed in current study can still be used to serve a foundation for future study concerning the aspects of HSCs expansion and maintenance.

\subsection{CONCLUSION}

In conclusion, NAC shows valuable property as antioxidant supplement for ex vivo maintenance of HSPCs by promoting their survivability and maintaining the clonogenic potency of respective myeloid, erythroid and pre-B lymphoid. Thus, future study focusing on genomic stability, clonogenicity, and oxidative status of respective progenitors in long terms ex vivo maintenance is important. This can further clarify the role of NAC for ex vivo maintenance of HSPCs without compromising stem cell potency for therapeutic and research usages.

\section{Acknowledgement}

This work was supported by FRGS (UKM) FRGS/1/2016/SKK13/UKM/03/1. The authors thank the Program of Biomedical Science, Faculty of Health Sciences and Bioserasi Laboratory for providing the place for conducting experimental works throughout this research.

\section{References}

[1] Bryder, D,. D. J. Rossi, and I. L. Weissman. 2006. Hematopoietic Stem Cells: The Paradigmatic TissueSpecific Stem Cell. The American Journal of Pathology. 169(2): 338-346. DOI: 10.2353/ajpath.2006.060312.

[2] Emerson, S. G. 1996. Ex Vivo Expansion of Hematopoietic Precursors, Progenitors, and Stem Cells: The Next Generation of Cellular Therapeutics. Blood. 87(8): 30823088.

[3] Spradling, A., D. Drummond-Barbosa, and T. Kai. 2001. Stem Cells Find Their Niche. Nature. 414(November): 98-104. DOI: $10.1038 / 35102160$

[4] Jang, Y. Y., and S. J. Sharkis. 2007. A Low Level of Reactive Oxygen Species Selects for Primitive Hematopoietic Stem Cells that May Reside in the Low-Oxygenic Niche. Blood. 110(8): 3056-3063. DOI: 10.1182/blood-2007-05-087759.

[5] Ren, Z. H., and Y. P. Jiang. 2013. Umbilical Cord Blood Hematopoietic Stem Cell Expansion Ex Vivo. Journal Blood Disorders \& Transfusion. S3: 1-6.

[6] Takagi, M. 2005. Cell processing Engineering for Ex Vivo Expansion of Hematopoietic Cells. Journal of Bioscience and Bioengineering. 99(3): 189-196. DOl: 10.1263/jbb.99.189.

[7] Watts, K. L., J. Adair, and H. P. Kiem. 2011. Hematopoietic Stem Cell Expansion and Gene Therapy. Cytotherapy. 13(10): 1164-1171. DOI: 10.3109/14653249.2011.620748.

[8] Liu, A. M., W. W. Qu, X. Liu, and C. K. Qu. 2012. Chromosomal Instability in In Vitro Cultured Mouse Hematopoietic Cells Associated with Oxidative Stress. American Journal of Blood Research. 2(1): 71-76.

[9] Abdul Hamid, Z., W. H. Lin Lin, B. J. Abdalla, , O. Bee Yuen, E. S. Latif, J. Mohamed, N. F. Rajab, C. Paik Wah, M. K. A. Wak Harto, and S. B. Budin. 2014. The Role of Hibiscus Sabdariffa L. (Roselle) in Maintenance of Ex Vivo Murine Bone Marrow-Derived Hematopoietic Stem Cells. The Scientific World Journal. 2014: 1-10. DOI: $10.1155 / 2014 / 258192$.

[10] Bigarella, C. L., R. Liang, and S. Ghaffari. 2014. Stem Cells and the Impact of ROS Signaling. Development (Cambridge, England). 141(22): 4206-18. DOI: 10.1242/dev.107086.

[11] Owusu-Ansah, E., and U. Banerjee. 2009. Reactive Oxygen Species Prime Drosophila Haematopoietic Progenitors for Differentiation. Nature. 461 (7263): 1-6. DOI: 10.1038/nature08313.

[12] Sardina, J. L., G. López-Ruano, B. Sánchez-Sánchez, M. Lianillo, and A. Hernández-Hernández. 2012. Reactive Oxygen Species: Are They Important for Haematopoiesis. Critical Reviews in Oncology/Hematology. 81 (3): 257-274. 
[13] Ludin, A., S. Gur-Cohen, K. Golan, K. B. Kaufmann, T. Itkin, C. Medaglia, X. Lu, G. Ledergor, O. Kollet, and T. Lapidot. 2014. Reactive Oxygen Species Regulate Hematopoietic Stem Cell Self-Renewal, Migration and Development, As Well As Their Bone Marrow Microenvironment. Antioxidants \& Redox Signaling. 21(11): 1605-1619. doi: 10.1089 /ars.2014.5941.

[14] Tothova, Z., R. Kollipara, B. J. Huntly, B. H. Lee, D. H. Castrillon, D. E. Cullen, and E. P. McDowell. 2007. FoxOs Are Critical Mediators of Hematopoietic Stem Cell Resistance to Physiologic Oxidative Stress. Cell. 128(2): 325-339.

[15] Ito, K., A. Hirao, F. Arai, K. Takubo, S. Matsuoka, K. Miyamoto, M. Ohmura, K. Naka, K. Hosokawa, Y. Ikeda, and T. Suda. 2006. Reactive Oxygen Species Act Through p38 MAPK to Limit the Lifespan of Hematopoietic Stem Cells. Nature Medicine. 12(4): 446-451. DOI: $10.1038 / \mathrm{nm} 1388$

[16] Aggarwal, R., J. Lu, V. J. Pompili, and H. Das. 2012. Hematopoietic Stem Cells: Transcriptional Regulation, Ex Vivo Expansion and Clinical Application. Current Molecular Medicine. 12(1): 34-49.

[17] Alves, H., A. Mentink, B. Le, C. A. van Blitterswijk, and J. de Boer. 2013. Effect of Antioxidant Supplementation on the Total Yield, Oxidative Stress Levels, and Multipotency of Bone Marrow-Derived Human Mesenchymal Stromal Cells. Tissue Engineering Part A. 19(7-8): 928-937. DOI: 10.1089/ten.tea.2011.0700.

[18] Hisha, H., H. Yamada, M. H. Sakurai, H. Kiyohara, Y. Li, C. Yu, N. Tokemoto, H. Kawamura, K. Yamaura, S. Shinohara, Y. Komatsu, M. Aburada, and S. Ikehara. 1997. Isolation and Identification of Hematopoietic Stem Cell-Stimulating Substances from Kampo (Japanese herbal) Medicine, Juzen-taiho-To. Blood. 90(3): 1022-1030.

[19] Dean, O., F. Giorlando, and M. Berk. 201 1. N-acetylcysteine in Psychiatry: Current Therapeutic Evidence and Potential Mechanisms of Action. Journal of Psychiatry and Neuroscience. 36(2): 78-86. DOI: 10.1503/jpn.100057.

[20] Kelly, G. S. 1998. Clinical Applications of N-acetylcysteine. Alternative Medicine Review. 3(2): 1 14-127.

[21] Parasassi, T., R. Brunelli, G. Costa, M. D. Spirito, E. K. Krasnowska, T. Lundeberg, E. Pittaluga, and F. Ursini. 2010. Thiol Redox Transitions in Cell Signaling: A Lesson from NAcetylcysteine. The Scientific World Journal. 10: 1192-1202.

[22] Berniakovich, I., L. Larrichia-Robbio, and J. C. I. Belmonte. 2012. N-acetylcysteine Protects Induced Pluripotent Stem
Cells From In Vitro Stress: Impact on Differentiation Outcome. International Journal of Developmental Biology. 56: 729-735

[23] Fan, J., H. Cai, S. Yang, L. Yan, and W. S. Tan. 2008. Comparison between the Effects of Normoxia and Hypoxia on Antioxidant Enzymes and Glutathione Redox State in Ex Vivo Culture of CD34+ Cells. Comparative Biochemistry and Physiology, Part B. 151:153-158.

[24] Human Colony-Forming Unit (CFU) Assays using MethocultTM. 2016. Stem Cell Technologies. 4.2.0: 1-52.

[25] Mouse Colony-Forming Unit (CFU) Assays using MethocultTM. 2015. Stem Cell Technologies. 3.2.0: 1-40.

[26] Ellman, G. L. 1959. Tissue Sulfhydryl Groups. Archives of Biochemistry and Biophysics. 82 (1): 70-77.

[27] Beyer, W. F., and I. Fridovich. 1987. Assaying for Superoxide Dismutase Activity: Some Large Consequences of Minor Changes in Conditions. Analytical Biochemistry. 161: 559566.

[28] Gupta, R., S. Karpatkin, and R. S. Basch. 2006. Hematopoiesis and Stem Cell Renewal in Long-Term Bone Marrow Cultures Containing Catalase. Blood. 107(5): 18371846. DOI: 10.1 182/blood-2005-03-1180.

[29] Chaudhari, A. A., J. W. Seol, S. J. Kim, Y. J. Lee, H. S. Kang, I. S. Kim, N. S. Kim, and S. Y. Park. 2007. Reactive Oxygen Species Regulate Bax Translocation and Mitochondrial Transmembrane Potential, A Possible Mechanism for Enhanced TRAIL-Induced Apoptosis by CCCP. Oncology Reports. 18: 71-76.

[30] Demirel, C., S. Kilçiksiz, O. I. Ay, S. Gürgül, M. E. Ay, and N. Erdal. 2009. Effect of $\mathrm{N}$-acetylcysteine on Radiationinduced Genotoxicity and Cytotoxicity in Rat Bone Marrow. Journal of Radiation Research. 50(1): 43-50.

[31] Maraldi, T., C. Angeloni, E. Giannoni, and C. Sell. 2015. Reactive Oxygen Species in Stem Cells. Oxidative Medicine and Cellular Longevity. 2015: 1-2. DOI: $10.1155 / 2015 / 159080$.

[32] Hunt, C. J. 2011. Cryopreservation of Human Stem Cells for Clinical Application: A Review. Transfusion Medicine and Hemotherapy. 38: 107-123.

[33] National Standards for Stem Cell Transplantation: Collection, Processing, Storage and Infusion of Hematopoietic Stem Cells and Therapeutic Cells. Ministry of Health, Malaysia, July 2009. MOH/P/PAK/188.09(BP). 